\title{
ATYPICAL FORMS OF EMPLOYMENT - A HINT OF PRECARIOUSNESS? STRUGGLING WITH THE SEGMENTATION AND PRECARISATION OF THE LABOUR MARKET*
}

\author{
Karla Kotulovski, PhD Candidate, Teaching and Research Assistant \\ Faculty of Law University of Rijeka \\ Hahlić 6, 51000 Rijeka, Croatia \\ kkotulovs@pravri.hr
}

\author{
Sandra Laleta, PhD, Associate Professor \\ Faculty of Law University of Rijeka \\ Hahlić 6, 51000 Rijeka, Croatia \\ sandra.laleta@pravri.hr
}

\begin{abstract}
Creation of more and better jobs is a central issue of the ILO's Decent Work Agenda, OECD's jobs strategy and the European Union's quality of work policies. While recent reports show an increase of new jobs in the European Union, the number of quality jobs is diminishing. On the other hand, there is a problematic mismatch between the education system and labour market needs. According to statistical data, Croatia is among the EU Member States with the highest rate of precarious work and the highest share of fixed-term employment in total employment. Almost a quarter of the Croatian population is at risk of poverty or social exclusion. Precarious work is closely related to non-standard or atypical forms of employment (e.g. part-time work, fixed-term employment, temporary agency work and (bogus or dependent) self-employment). These forms of employment have negative consequences for the functioning of the labour market, individual workers and the society as a whole. The authors underline shortcomings of the Croatian legislation regarding atypical forms of employment and give possible solutions that could improve the employment status and social security entitlements of those categories of workers.
\end{abstract}

Keywords: atypical forms of employment, precarious employment, EU, Croatia

This paper is written under support of the University of Rijeka Research Project "Legal Aspects of Companies Restructuring and Transition Towards New Corporate Governance Culture" (uniri-drustv-18-43) 


\section{INTRODUCTION}

The new world of work is strongly marked by precariousness. This phenomenon appears in different forms in the labour market. Employers use different forms of work that enable them to be very creative and circumvent rules, while exploiting legal lacunas and uncertainties to increase profit and stay competitive often at the expense of their employees. Precarious employment has become the key occupation of the contemporary labour legislation that notes a rise of precariousness in employment. ${ }^{1}$ Precarious work is closely related to non-standard or atypical forms of employment (e.g. part-time work, fixed-term employment, temporary agency work and (bogus or dependent) self-employment). The latter have negative consequences for the functioning of the labour market, individual workers and the society as a whole. The authors question whether precariousness is inherent to the non-standard forms of employment and its temporary nature, and whether it is releated exclussively to the specific form of employment and its legal shortcomings or the phenomenon lies in a combination of work arrangement and organizational anomalies and personal perception of the work process. This represents the basis for analysing the capability of the Croatian market to respond to demands for functional flexibility in the form of non-standard employment. According to statistical data, Croatia is among EU Member States with the highest rate of precarious work and the highest share of fixed-term employment in total employment. Almost a quarter of the Croatian population is at risk of poverty or social exclusion. The authors underline the shortcomings of the Croatian legislation regarding atypical forms of employment and provide possible solutions that could improve the employment status and social security entitlements of these categories of workers. Within this article the terms non-standard work and atypical work will be used as synonymus.

\section{ATYPICAL FORMS OF EMPLOYMENT AND THE LABOUR MARKET}

Precarious work continuously attracts attention at the EU level. One of the crucial questions in the context of EU social policy concerns the efficiency of positive law and the protection of precarious workers. This question hence centres on the extent of the scope of basic rights to all persons that perform some form of personal work in order to deter or at least control the labour market transition into more precarious spheres. The insecurity in the world of labour challenges the funda-

Ross, S., The Rise of Precarity, Ontario Secondary School Teachers Federation magazine, Education Matters, Understanding and navigating the emerging economic and social (dis)order, 2017, [https:// labourstudies.mcmaster.ca/news/the-rise-of-precarity], Accessed on 12. April 2020 
mental principles of the European Social Model (ESM) concerning the security of employment relationship and decent social protection as a result of labour market fragmentation and social polarization. ${ }^{2}$ One of the ambitious aims of the European Pillar of Social Rights (EPSR), as an official document of the EU, is to create the conditions for better and more quality life and working environment in the EU. For the first time it emphasizes expressis verbis the notion of precariat as a challenge facing modern European legislation. ${ }^{3}$ Therefore, it's unsurprising that precarious work and the impact of precarisation on employment law of the EU and EU Member States is a trending topic among the academic society. ${ }^{4}$

\subsection{Atypical equals precarious?}

Since 1970 es the labour market has been upgraded by atypical employment relations, thus adapting to (overlapping) megatrends, such as globalisation, digitalisation, demographic changes, industrial restructuring, remodelling of labour force and erosion of social standards due to weakening of the trade unions' bargaining power and the growing trend of declining membership. ${ }^{5}$ The growing number of available forms of employment enables the labour market participants to adapt to the growing economic competition, with the goal of creating an added value, that often causes a reduction of the workers' protection. ${ }^{6}$

The introduction of non-standard employment in the EU was the reflection of the labour market structural changes and the individual interests of its participants, that dictate the increase of part-time work, temporary work and self-employment, as well as 'compound' non-standard employment, i.e. very marginal part-time work, very short temporary contract, working without a contract and casual work. 7 Their number and variety is increasing, especially in the Central, Eastern and Southern Europe, where trade unions as social partners are being marginalized

2 European Commission (et al) Launching a Consultation on a Euopean Pillar of Social Rights, 127 Final, Strasbourg, 2016

3 Europan Pillar of Social Rights in 20 Principles, [https://ec.europa.eu/commission/priorities/deeper-and-fairer-economic-and-monetary-union/european-pillar-social-rights/european-pillar-social-rights-20-principles_en], Accessed on 01. March 2020

4 Fudge, J.; Owens, R., Precarious Work, Women, and the New Economy: The Challenge to Legal Norms, in: Fudge, J.; Owens, R. (eds.), Precarious Work, Women, and the New Economy: The Challenge to Legal Norms, Hart Publishing, 2006

5 Stone, K. V. W., From Widgets to Digits, Employment Regulation for the Changing Workplace, Cambridge University Press, USA, 2004, p. 69

6 Matković, T., Nestajanje rada? Opseg i oblici zaposlenosti na početku informacijskoga doba, Društvena istraživanja, vol. 13, no. 1-2, 2004, pp. 69-70

7 Eurofound (2020), Labour market change: Trends and policy approaches towards flexibilisation, Challenges and prospects in the EU series, Publications Office of the European Union, 2020, p. 2 
due to often unilateral governmental decisions. ${ }^{8}$ These employment forms represent a deviation from the standard of core employment that presupposes stable and secure employment with clearly defined rights and responsibilities and visible carrier perspective, why we call them atypical or non-standard. ${ }^{9}$ The employers need operative flexibility in order to adapt quickly to the market changes caused by technological innovations. ${ }^{10}$ That becomes possible by means of a combination of core labour, multi-skilled non-replaceble workers, on the one hand, and marginal, periphery, single-skilled workers who perform temporary or casual job, employed (directly or indirectly) through atypical forms of employment, on the other. ${ }^{11}$ Recent research "had often lead to the conclusion that the one of the largest and fastest growing problems in Europe is labour market dualization, that is, an increasing divide between insiders in permanent employment and outsiders in precarious work or unemployment." 12

Strict employment protection legislation (EPL) is often considered as the main cause for the labour market segmentation, due to which standard workers can easily be replaced with flexible, adaptable, cheap, precarious labour force, precariat, ${ }^{13}$ and which should be deregulated. ${ }^{14}$ Traditionally, precarity is connected with time-limited forms of employment, but as will be shown, precarity and atypical employment cannot be equalized. ${ }^{15}$ Moreover, the erosion of labour standards and

8 Butković, H. et al., Nestandardni rad u Hrvatskoj: Izazovi i perspektive u odabranim sektorima, IRMO, Zagreb, 2018, p. 19

9 At which point has the standard become an exception? Some research attributes the dominance of the SER to increased self-employment. See: Eurofound (2017b), Non-standard forms of employment: Recent trends and future prospects, Eurofound, Dublin, 2017, p. 5

10 Flexibilisation in employment can refer to numerical, spatial or functional flexibility. See: Labour market change, note 7, p. 9

11 For core/periphery model see: Huws, U. et al., What price flexibility? The casualisation of women's employment, 1989, [https://openaccess.leidenuniv.nl/bitstream/handle/1887/35203/What $\% 20$ price $\% 20$ flexibility.pdf?sequence=1], Accessed on 01. March 2020, p. 10

12 Florczak, I.; Otto, M., Precarious work and labour regulation in the EU: current reality and perspectives, in: Kenner, J. et al. (eds.), Precarious work: towards a new theoretical foundation, The challenge for Labour Law in Europe, Edward Elgar, Cheltenham, Northampton, 2019, p. 2

13 Standings defines precariat as group of workers in labour market who lack several forms of social and legal security. See: Standing, G., Precariat: New Dangerous Class, Bloomsbury Academic, London, 2011

14 Employment in Europe Report noted that stict EPL sustaining SER contributes to labour market segementation, high use of temporary contracts with low protection and limited prospects for permanent employment. Employment in Europe Report, 2007, p. 51

15 Besides the so-called classic atypical forms of employment, Quinlan mentions five categories of precarious, insecure work: casual work; work in which the workers are exposed to organizational changes (including restructuring, reduction of the employees, privatization); outsourcing (inclucing homework), part-time work, and small business work (including self-employment). Quinlan, M. et al., The Global Expansion of Precarious Employment, Work Disorganization, and Consequences for Occupational Health: 
increased insecurity did not outmanoeuvre the permanent form of employment. ${ }^{16}$ It should be stressed that Eurofound has mapped nine relatively new working arrangements in EU28 and Norway, ${ }^{17}$ which, although useful both for employers and workers, provoke justified concern because of their impact on working conditions and the labour market in general.

\subsection{Flexicurity - an effective means for combating precariousness or a "shiny" political instrument}

As mentioned above rigid labour legislation (on high employment protection) was seen as harmful for the labour market. This has been addresses in the form of the policy of deregulation both at the EU and Member States level over the past three decades, including also the concept of flexicurity. ${ }^{18}$

Constituting the official EU employment policy ever since 2007, the concept of flexicurity was meant to provide the necessary flexibility of employment for employers, on the one hand, and adequate protection (security) of employees, on the other hand. However, there are not only doubts regarding its effectiveness, ${ }^{19}$ but also widespread concerns that "the persistent lack of a right balance between flexibility and security has resulted in the precarization of atypical employment's working relations." ${ }^{20}$ Consequently, the old questions arise of whether the fascination with the concept of flexicurity is justified, ${ }^{21}$ or has it achieved its purpose or just brought popularity to its creators without real effect and sustainability. ${ }^{22}$

A Review of Recent Research, International Journal of Health Services, vol. 31, no. 2, 2001, pp. 335414

16 Marshall, A., The Sequel of Unemployment, The Changing Role of Part-time and Temporary Work in Western Europe, in: Rodgers, G.; Rodgers, J. (eds), Precarious Job in Labour Market Regulation, Geneva: Institutional Institute for Labour Review, 129, 1989, p. 17-30

17 Eurofound (2015), New Forms of Employment, [https://www.eurofound.europa.eu/hr/ new-forms-of-employment\#case\%20studies], accessed on 03. March 2020

18 Florczak; Otto, op. cit, note 12, p. 8

19 It did not bring any novelty in the EU Employment Policy regulation of the precarious employment. Report by the „Flexicurity“ Mission (2008) in: Kountouris, N., The Legal Determinants of Precariousness in Personal Work Relations: A European Perspective, Comparative Labour Law \& Policy Journal, vol. 34, no. 1, 2012, pp. 39-40

20 Florczak; Otto, op. cit, note 12, p 7

21 Bodiroga - Vukobrat, N. et al., Precarious Times, Precarious Work: Lesson from Flexicurity, in: Wolfrum, R. et al. (eds.), Contemporary Developments in International Law. Essays in Honour of Budislav Vukas, Brill Nijhoff, Leiden, Boston, 2016, p. 408

22 Henning, J. et al., Flexicurity and Beyond. Finding a new agenda for the European Social Model, DJØF Publishing, Kopenhagen, 2007 
The concept of flexicurity suggests different roads Member State can take to improve their labour markets. This variety and diversity of welfare states across Europe is documented by many studies. ${ }^{23}$ However, flexibilisation in the labour market could be seen as a neutral concept, beneficial to both employers and workers, only im implemented properly, depending on specific individual situations and regulatory frameworks, so as to ensure a win-win situation for both sides. ${ }^{24} \mathrm{Never-}$ theless, the traditional conflict of interests in the world of labour full of emerging needs and novelties, in which workers more often accept insecure and changeable working conditions that create a feeling of individual uncertainity, deserves the intervention of labour law in offering an optimal solution. ${ }^{25}$

\subsection{The notion of precarious work}

Pecarious work is not a matter of a single state, but a hallmark of the contemporary world of work in general. If we want to develop (more) effective means (or regulation) to combat this negative phenomenon universally, we need an appropriate regulatory response, comprehensive policy and workers empowered by promoting collective bargaining and right to associate, as well as minimum wages (globally) and basic income security. ${ }^{26}$ In achieving this, contemporary labour law legislation and situation at the labour market call for a universal (comprehensive) definition of precarious work, that includes clear indicators and dimensions of precariousness. Despite the proliferation of scientific publications and studies about precarious work, the concept still remains unclear. ${ }^{27}$ One of the reasons is the economic, social, political, and labour market diversity in different states. ${ }^{28}$ However, the majority of academics agree that precarious employment is a multidimensional and heterogeneous phenomenon that contains a combination of insecurity, instability, socio-economic vulnerability and the lack of protection. ${ }^{29}$

23 Wilthagen, T. et al., Flexicurity Pathways: Turning Hurdles into Stepping-Stones, Brussels, 2007

24 Eurofound (2020), note 7, p. 3

25 Godlewska-Bujok, B.; Patulski, A., Precariat: next stage of development or economic predominance in a new scene?, in: Kenner, J. et al. (eds.), Precarious work: towards a new theoretical foundation, The challenge for Labour Law in Europe, Edward Elgar, Cheltenham, Northampton, 2019, pp. 25-26

26 ILO (2012), From precarious work to decent work, Bureau for Workers' Activities, International Labour Office, Geneva, 2012, p. 22

27 It seems that the insecurity that is a characteristic of the atypical employment arrangements has been transmitted to the research. Starčević, M., Prekarni rad i nemogućnost prekarne klase, Diskrepancija, vol. 13 , no. 19, 2014, p. 38. The same is true of science when using "precarious employment" as a notion that is not a statistical category

28 ILO (2011), Policies and Regulations to Combat Precarious Employment, Bureau for Workers Activities, International Labour Office, Geneva, 2011, p. 5

29 About reflexive question: How the precariousness has become a multi-dimensional phenomenon? In: Badoi, D., Normalizing precariousness through the flexible work -A conceptual model proposal for the 
Even though these characteristics are associated to atypical employment, as (highly) precarious, non-standard or atypical categories of work, they cannot be equated with precarious employment, ${ }^{30}$ but may, nevertheless, be used as a starting point for our analysis.

The European Commision has addressed the challenges of precarious work. One study concluded that the precarious work includes different forms of employment "established below the socially accepted normative standards (typically expressed in terms of rights, of employment protection legislation, and of collective protection) in one or more respects (the four dimensions) which results from an unbalanced distribution towards and amongst workers .... of the insecurity and risks typically attached to economic life in general and to the labour market in particular..." ${ }^{31}$ Different research shows that in general, all employment relationships are at some risk of precarization, ${ }^{32}$ depending on the individual context and the type of risk connected to a specific employment relationship. EU Member States that have the highest share of SER have, contrary to logic, the highest risk of precarization. ${ }^{33}$ Precariousness is indeed closely connected with digitalization and "gig economy". ${ }^{34}$ The stable resp. permanent employment relationships are also exposed to precariousness in a situation where employer does not pay wage due to insolvency ${ }^{35}$ and, on the other hand, because of low salaries, unpaid obligatory

precarization of early-stage workers in science and research, [http://www.inclusivegrowth.eu/files/Call12/15-DBadoi-_paper.pdf], accessed on 01. March 2020, in connection with: Bodiroga-Vukobrat et al., op. cit., note 21, p. 406

30 Non-standard work include various types of employment status as found in labour law and reflected in conventional labour market statistical categories. Eurofound (2018a), Non-standard forms of employment: Recent trends and future prospects, Eurofound, Dublin, 2018

31 Hromadžić, H.; Zgaljardić, A., Prekarnost, Ekonomsko-politički i društveni fenomen suvremenog svijeta, Etnološka tribina 42, vol. 49, 2019, p. 123

32 Share of the open-ended employment contracts in total employment is almost $60 \%$ and shows continuous growth. Precarious Employment in Europe: Patterns, Trends and Policy Strategies, 2016, p. 10-11, [http://www.europarl.europa.eu/studies, 10.2.2020], accessed on 03. March 2020

33 Ibid.

34 Eurofound (2017), Aspects of nonstandard employment in Europe, Dublin, Eurofound, 2017

35 It is estimated that in Croatia around 40.000 workers from the private sector, sector of services, craft and retail work, but do not receive salary. Most of them are not organized in trade unions and not covered by a collective agreement in force in their company. There are no official data about the number of workers that perform work but do not receive salary, because the employer in Croatia has to pay taxes and obligatory contributions first, and afterward salary. Also, the employer is not obliged to notify the authorities about the number of the workers he did not remunerate for their work. [https://www. moj-posao.net/Press-centar/Details/68737/Izmedju-40-i-60-tisuca-ljudi-radi-a-ne-prima-placu/2/], accessed on 10. March 2020 
social security contributions, and/or access to the mechanisms of protection. ${ }^{36} \mathrm{It}$ is possible to conclude hence that precariousness is inherent to every working process, and not only to atypical forms of employment. ${ }^{37}$ Despite the high EPL and social security, a worker employed based on an open-ended contract is equaly "vulnerable" in terms of indicators that make work insecure or less secure. As Grimshaw emphasizes, if SER is taken as a referent value of "quality work", it should also be aware of the diversity of national standards that guarantee the protection of this type of model and the fact that many national legislations have relaxed the SER protection. ${ }^{38}$ The main risks related to SER are: low rewards (income precariousness), exposure to stress (psychological precariousness), questionable career perspective and limited acces to professional trainings (organizational precariousness). ${ }^{39}$ From the perspective of temporal precariousness, part-time worker's sense of (financial) instability and (social) insecurity may continue transforming into a standard employment relation which, although representing "job-for-life" per se does not create a lasting and unbreakable bond between employer and employee that could not be terminated. ${ }^{40}$

\subsection{Non-standard employment - personal choice rather than involuntary work}

Besides the legislative approach ${ }^{41}$ the criterion of personal choice of a flexible working arrangement can be used to determine whether a certain flexible employment is precarious or not. One of the best examples is part-time work as the most important instrument of flexibilization over the last decade, with a share of over $20 \%$ in total employment in $2018 .{ }^{42}$ According to some authors, a worker who

36 Ori, M.; Sargeant, M., Introduction, in: Precarious Work and Vulnerable Workers, Vulnerable Workers and Precarious Working, International School of Higher Education in Labour and Industrial Relations, Cambridge Scholars Publishing, Newcastle upon Tyne, 2013

37 Kountouris, $o p$. cit., note 19, p. 22

38 Still, standard employment - permanent, full-time employment subject to labour regulation - is still dominant employment form in Europe. Grimshaw, D. et al., Reducing Precarious Work Protective gaps and the role of social dialogue in Europe, 2017, p. 6, [https://www.epsu.org/sites/default/files/article/ files/Precarious\%20work\%20and\%20social\%20dialogue.pdf], accessed on 07. March 2020

39 Ibid.

40 Florczak; Otto, op. cit., note 12, p. 8

41 Directive 97/81/EC defines part-time worker as "an employee whose normal hours off work (...) are less than the normal hours of work of a comparable full-time worker. "Minority of interviewed Member States overall perceived part-time work as precarious. However, study respondents described part-time work as the main issue for the social partners with employers arguing for the liberalisation of restrictions on part-time working and trade unions supporting the existing limits on part-time work. See: Countouris, N., Strengthening the protection of precarious workers: the concept of precarious work, ITC, London, $<$ s.a.>, p. 4

42 Managers, for instance are much less likely to be working part-time and, if working part-time, to be doing so involuntary. Eurofound (2018), Non-standard forms of employment: Recent trends and 
choses part-time work in order to achieve work-life balance should not be deemed to be precariously employed. Conversely, if a part-time worker has no possibility to increase working hours, he or she is confined by a lower-paid employment with limited career perspectives; consequently, the lower-quality employment prompts precariousness. ${ }^{43}$

Taking into account the regulatory inefficiency of the Part-time work Directive $97 / 81 / \mathrm{EC},{ }^{44}$ there are significant differences in national legislations of the Member States concerning the regulation of the part-time worker's right to request the move to more secure type of employment, resp. move from part-time work to full-time work. ${ }^{45}$

In Croatia, under the Art. 62 par. 7 of the Labour Act (LA), the employer is obligated to consider the request of the worker for change in the duration of working hours agreed by the employment contract, from part-time to full-time and vice versa. As this is a way for workers wishing to incease the working hours and earnings, and/or secure permanent position in undertaking or establishment, ${ }^{46}$ it seems to be an instrument against precariousness. However, the employer has this obligation only if a possibility for that type of work in his enterprise actually exists. It is important to note that the wording of the provision is not precise, and consequently the employer's obligation remains unclear and vague. Croatian workers choose to work part-time mostly involuntarily in the absence of full-time employment opportunities. ${ }^{47}$ For some authors, involuntary acceptance of atypical form of employment in the absence of alternative solutions represents hence precarious employment in which the elements of the security of a full-time job is missing. ${ }^{48}$ While in the EU the percentage of part-time workers is growing, in

future prospects, Dublin, p. 9 See also: Countouris, Strengthening, op. cit., note 41

43 Eurofound, 2020, Labour market change, note 7, p. 21

44 Council Directive 97/81/EC concerning the Framework Agreement on part-time work concluded by UNICE, CEEP and the ETUC - Annex: Framework agreement on part-time work) [1997] OJ L 14/9 (Part-Time Work Directive)

45 Westregård, A., Is Permanent Employment the Solution? Precarity on new forms of employment under Swedish labour law, in: Kenner, J. et al. (eds.), Precarious work: towards a new theoretical foundation, The challenge for Labour Law in Europe, Edward Elgar, Cheltenham, Northampton, 2019, p. 108

46 European Commission, Commission Staff Working Document: Analytical document accompanying the Consultation Document Second phase consultation of Social Partners under Article 154 TFEU on a possible revision of the Written Statement Directive (Directive 91/533/EEC) in the framework of the European Pillar of Social Rights, SWD(2017)301 final, Brussels, 2017

${ }_{47}$ Who are involuntary part-time workers? See in: Eurofound (2017a), Estimating labour market slack in the European Union, Publications Office of the European Union, Luxembourg; Eurofound „Aspects of nonstandard employment in Europe" Dublin, 2017

48 Report VI: Employment Policies for Social Justice and Fair Globalization, ILO, 2010, p. 35, in connection with: Employment in Europe, 2007, p. 47 (Directorate-General for Employment, Social Af- 
Croatia it is falling (in 2017 it amounted to 4,8\%) with women working mostly as part-time employees. ${ }^{49}$ Research has shown that the precarious position of female part-time workers is manifested in non-equal access to professional training and possibility of promotion (organizational precariousness) and significantly lower average wage (income precariousness) in relation to male workers, that causes a more visible unequal access to pension schemes and consequenty, growing risk of social exclusion.

\subsection{De lege lata solution at the EU level - still searching for a comprehensive definition of precariousness}

It seems that the "atypical" Directives are a good example of an intersection of precarious labour elements and secondary EU law. Part-Time Work Directive (like the Fixed-Term Work Directive and Temporary Agency Work Directive) ${ }^{50}$ uses the principle of equal treatment to equalize the status of atypical and comparable permanent worker. ${ }^{51}$ Earlier research shows that the latter directives were not efficient enough in decreasing the existing differences regarding access to professional education, safety and health at work protection, and social protection of atypical workers in relation to permanent workers. ${ }^{52}$ Still, I. Florczak emphasizes that the violation of the principle of equal treatment is not sufficient for the development of precarious employment, just as precarious employment is not always a consequence of unequal treatment. ${ }^{53}$

In 2016 the European Commission emphasized that flexible labour market policy should enable the transition to more secure and more permanent forms of em-

fairs and Equal Opportunities Unit, 2007)

49 Also see: The Gender Pay Gap in Belgium, Report, 2014, [https://igvmiefh.belgium.be/sites/default/ files/78_-_gender_pay_gap_report_2014_eng_0.pdf ], accessed on 12. April 2020

50 Part-Time Work Directive, note 44; Council Directive 1999/70/EC concerning the framework agreement on fixed-term work concluded by ETUC, UNICE and CEEP [1999], OJ L175/43 (Fixed-Term Work Directive); Directive 2008/104/EC of the European Parliament and of the Council on temporary agency work [2008] OJ L327/9 (Temporary Agency Work Directive)

51 Whether the temporary and permanent workers of the same enterprise are comparable should be assesed taking into account different factors, e.g. nature of work, conditions for professional training, and working conditions. See the Judgments of the CJEU: Case C-177/10 Francisco Javier Rosado Santana v Consejería de Justicia y Administración Pública de la Junta de Andalucía (EU:C:2011:557, 66., 8.9.2011) and Case C-38/13 Matgorzata Nierodzikv Samodzielny Publiczny Psychiatryczny Zaktad Opieki Zdrowotnej im. dr. Stanistawa Deresza w Choroszczy (EU: C:2014:152, 13.3.2014)

52 Eurofound (2018), Does employment status matter for job quality?, Publications Office of the European Union, Luxembourg, 2018, p. 4-7

53 Florczak; Otto, op. cit., note 12, p. 13 
ployment. ${ }^{54}$ Social partners in Europe have an important role in limiting precarious work through national legislation and collective bargaining at lower levels. For example, the Slovenian trade unions strive for the convertion of temporary resp. casual working arrangements into permanent employment, nevertheless, there are quite different examples as well. ${ }^{55}$

The Report of the European Parliament contains guidelines that represent a contribution to the indeed necessary basic consensus about the notion of precariousness. Precarious employment is therein defined as "employment which does not comply with EU, international and national standards and laws and/or does not provide sufficient resources for a decent life or adequate social protection"; precariousness depends on the type of contract that has been concluded, but also on one of following factors: "little or no job security owing to the non-permanent nature of the work, as in involuntary and often marginal part-time contracts, and, in some Member States, unclear working hours and duties that change owing to on-demand work; rudimentary protection from dismissal and lack of sufficient social protection in case of dismissal; insufficient remuneration for a decent living; no or limited social protection rights or benefits; no or limited protection against any form of discrimination; no or limited prospects for advancement in the labour market or career development and training; low level of collective rights and limited right to collective representation; a working environment that fails to meet minimum health and safety standards." ${ }^{56}$ Such a multidimensional approach to precarious employment that uses different indicators is not new. Rodgers and Rodgers differentiate the temporal, organizational, economic and social precariousness. ${ }^{57}$

Nevertheless, while analysing precariousness we should bear in mind that legal norms do not include personal, psychological and/or existential indicators of precariousness that could create different perceptions of insecurity of a concrete form of employ-

54 Annual Growth Survey, 2016, COM/2015/0690 final. Unlike Germany and UK where standard open-ended contracts represent the most prevalent employment relationship, France and Spain are characterised by a high incidence of non-standard employment and quite low transition rates into standard forms of employment. Eurofound (2019), Labour market segmentation: Piloting new empirical and policy analyses, Publications Office of the European Union, Luxembourg, 2019, p. 22

55 In Latvia they support labour market flexibility. Bejaković, P., Prekarni rad u Hrvatskoj i Europi, Radno pravo, no. 7-8, 2019, p. 36

56 European Parliament, Report on working conditions and precarious employment (2016/2221(INI)), [https://www.europarl.europa.eu/doceo/document/A-8-2017-0224_EN.html], accessed on 10. March 2020

57 Rodgers, G., Precarious Work in Western Europe: The State of the Debate, in: Rodgers, G.; Rodgers, J. (eds.), Precarious Jobs in Labour Market Regulation: The Growth of Atypical Employment in Western Europe, ILO, Geneva, 1989 
ment, in relation to age, sex, psychological status of worker, his/her family and social conditions. ${ }^{58}$ Therefore, individual, subjective experiences of a concrete job can create a positive perception of an otherwise objectively "low-quality" (bad) job. ${ }^{59}$

Another challenge in the battle against precarious work is related with the application of the social policy directives rationae personae, i.e. in regard to the effectiveness of the guaranteed rights. Some categories of precarious workers (self-employed, on-call workers) ${ }^{60}$ fall within the concept of "worker" in EU law according to the established case law of the CJEU. On the other hand, the application of Part-time and Fixed-term Directives to other categories of workers "may be dependent upon the relevant national legal definitions and practices". ${ }^{61}$ Such interpretation of the concept of worker creates a gap in the protection of workers employed in the atypical forms of work, that do not fullfil the criteria for a contract of employment or employment relationship. ${ }^{62}$ This triggered the drafting of "Protection Against Precarious Work Directive" based on the principle of equal treatment, protection against abuses and facilitation of access to typical forms of employment. ${ }^{63}$

Another issue closely related with the precariousness of work that draws attention is the creation of "quality jobs", regardless of the contractual form. The latter issue is also manifested in the revision of the Written Statement Directive ${ }^{64}$ and the

58 Kountouris, op. cit., note 19, p. 22

59 Subjective experience is the basic way to find out „to what extent is precariousness transmitted to worker." See: Campbell, I.; Price, R., Precarious work and precarious workers: Towards an improved conceptualisation, The Economic and Labour Relations Review, vol. 27, no. 3, 2016, pp. 316-318

60 Case C-143/16 Abercrombie \& Fitch Italia Srl v Antonino Bordonaro, EU:C:2017:566 (19 July 2017) with legal updates on this case: link: Use of zero hours contracts for young workers, with automatic dismissal at age 25, not unlawful age discrimination (ECJ); Case C-66/85 Deborah Lawrie-Blum v Land Baden-Württemberg, [1986] ECR 02121

${ }_{61}$ Florczak; Otto, op. cit., note 12, p. $18 \mathrm{ff}$

62 The application of the concept of worker is problematic in frame of potentially most relevant PartTime and Fixed-Term Directives. Florczak; Otto, ibid., p. 19; in connection with: Kountouris, N., The Concept of 'Worker' in European Labour Law: Fragmentation, Autonomy and Scope, 2018, p. 197, [https://discovery.ucl.ac.uk/id/eprint/1571889/1/Countouris_Concept_Worker_European_AAM. pdf], accessed on 02. February 2020

63 Garben, S. et al., Towards a European Pillar of Social Rights: Upgrading the EU social aquis, Theorising the ENP -Conference Report, 2015, p. 5. Kountouris emphasized that Directives depart from the aproach that "atypical equals precarious" (and vice versa), and consequently the best way to deprecarize the atypical work is "to make its regulation conform to that of the standard employment relationship“. Kountouris, op. cit., note 19, p. 37-38

64 Council Directive 91/533/EEC on an employer's obligation to inform employees of the conditions applicable to the contract or employment relationship [1991] OJ L288/32 - Writtent Statement Directive is the first instrument of secundary law with which the EU began to regulate „atypical“ work. European Commission, Staff Working Document REFIT Evaluation of the "Written Statement Directive" (Directive 91/533/EEC) SWD (2017) 205 final 
extension of the minimum rights, resp. social dialogue, collective bargaining and freedom of association, to all workers, including precarious workers, with the view of promoting security and information about all aspects of employment relationship. The idea of a comprehensive policy that guarantees an efficient protection at the workplace in order to eliminate the trend of precariousness was realized in June 2019, when the Directive on Transparent and Predictable Working Conditions in the Union, with a special emphasis on atypical forms of employment, was adopted. ${ }^{65}$

\section{THE QUALITY-DECENCY WORK PERSPECTIVE TO INVESTIGATE PRECARIOUS EMPLOYMENT}

Notions of "precarious employment" and "quality of employment" share the same difficulty of finding or developing appropriate indicators that could be used to classify (in a metodologically satisfactory way) certain work as precarious, i.e. to classify an employment relationship as (non)-quality employment. As this is a topic warranting a detailed investigation, several issues need to be addressed. Competitive economy should not be based on a permanent decrease of the quality of jobs, especially when the statistics and trends show that the high employment rate goes hand in hand with the quality of jobs. Moreover, earlier research demonstrates that a job is of lower quality if work is performed based on temporary working arrangements, in contrast to permanent employment relationships, which is most notable in the difference in the amount of salary of the permanent and temporary worker, the access to specific rights like professional training or trade union membership. ${ }^{66}$

In spite of the so far (pre-Covid) positive economic indicators for Croatia, ${ }^{67}$ a stable trend of a decrease of quality jobs has continued, which seems to be true of the economic growth based on the reduction of workers' rights too. A recent study found that the working conditions of a great number of workers are similarly bad or worse than before the recession of 2008. Consequently, one quarter of the population is on the brink of poverty or social inclusion risks. ${ }^{68}$ This data shows that

65 Directive 2019/1152 of the European Parliament and of the Council on transparent and predictable working conditions in the European Union [2019] OJ L186/105

66 More at: Union of Autonomous Trade Unions of Croatia (Savez samostalnih sindikata Hrvatske); its Project: Work at the measure of workers; available at: [http://www.sssh.hr/hr/vise/nacionalne-aktivnosti-72/rad-po-mjeri-covjeka-3446], accessed on 24. April 2020

67 In 2018 the real growth of the GDP amounted to 2,6\%, thereby the trend of the economic activity's recovery commenced in 2015 after 6 years of reccession. Convergence Program 2019-2022, Ministry of Finance, Croatia, 2019 [https://ec.europa.eu/info/sites/info/files/business_economy_euro/ economic_and_fiscal_policy_coordination/documents/2019-european-semester-convergence-programme-croatia-hr.pdf], accessed on 04. March 2020

68 Tomić, I. et. al., The employment and social situation in Croatia, Policy Department for Economic, Scientific and Quality of Life Policies, EU, 2019, p. 8, [http://www.europarl.europa.eu/supporting-anal- 
the social benefits are not an efficient tool for the reduction of poverty as, comparing to the period $2013-2018$, a decline in benefits has been marked. ${ }^{69}$ According to the Commission, one of the positive indicators of the efforts undertaken by the Croatian legislation to reduce poverty and social exclusion is the above mentioned duty of the employer to consider the worker's request to transfer from part-time to full-time and vice versa. However, the efficiency of such regulation (infra 4) could be achieved by additional measures, e.g. the employer's duty to answer in a written form or to guarantee a priority to part-time worker, which have been introduced in several Member States. ${ }^{70}$

Responses of the national economies to the global labour market competition, in line with the European legislation, disturbe the social structure and push non-standard workers into poverty. ${ }^{71}$ The research of the European Commission illustrates that more than $40 \%$ of all employment contracts are related to non-standard forms of work ranging from regular part-time work to on-demand work without guaranteed working hours. ${ }^{72}$ Therefore, it is important to ensure decent work, including decent wage to avoid in-work poverty. ${ }^{73}$

Adressing precariousnes in work, the EPSR emphasizes the right to fair wages that provide for a decent standard of living. It underlines that precariousness should be analysed independently from the form of employment, and based on the decent standard of living that could be disrupted by bad working conditions. ${ }^{74}$ Regardless of the generally accepted understanding of decent living conditions, if their realization is ensured by the financial indicator - adequate remuneration - we could indeed label a particular job secure and in turn non-precarious. Consequently, an adequate wage should be ensured and regulated in line with the national social and economic conditions of the Member State in order to prevent in-work poverty.

yses], accessed on 12. April 2020

69 Ibid.

70 European Commision, Right to request a different form of employment and receive a reply in writing, 2017, p. 118-119. About the inefficiency of Part-Time Directive, see: Eurofound, 2020, Labour market change, note 7 , p. 1

71 Izvješće o uvjetima rada i nesigurnosti radnih mjesta, Europski Parlament, 2017, [http://www.europarl.europa.eu/doceo/document/A-8-2017-0224_HR.html], accessed on 01. April 2020

72 Extent of NSE in the EU, European Commission, Non-standard employment and access to social security benefits, Research note 8/2015 (SMM_2015_RN8_non-standard employment_final (2).pdf)

73 Peña-Casas, R. et al., In-work poverty in Europe, A study of national policies, European Social Policy Network (ESPN), Brussels, European Commission, 2019, p. 7. See also ILO definition of decent work in: ILO (2016), Non-standard employment around the world, Understanding challenges, shaping prospects, International Labour Office, Geneva, 2016, p. 3

74 Cf. Florczak; Otto, op. cit., note 12, p. 13-14. Some authors observe: "A guaranteed minimum income may have an important role in reducing IWP — when it can be (temporarily) combined with work income" as a strengthen income replacement policy. Peña-Casas, et al., ibid., p. 16 
In 2020 the minimum net wage in Croatia amounts to 3.250,01 Kuna (cca 440 EUR). Working for a minimum wage does not necessarily mean living in poverty, while the poverty depends on the economic status of a household, resp. the duty of the wage earner to support other persons or not. ${ }^{75}$

Concerning the social security aspects, Grgurev and Vukorepa warn that in Croatia fixed-term employment (and temporary agency work) is potentially problematic in the case of low wages and longer career breaks between two employment contracts. In order to avoid marginalisation of workers engaged in flexible forms of employment, it is important to reflect more on state measures which could be introduced. $^{76}$

To conclude, the above mentioned relations are connected in straightforward ways. Although still subject to debate, they seem to offer useful guidance in empirical research of precarious employment.

\section{LEGISLATIVE DEVELOPMENTS IN FIXED-TERM CONTRACTS - WHERE DO WE STAND?}

The standard employment relationship is still prevalent in most EU Member States. But employers often engage workers based on employment contract (or relationship) of limited duration, determined by objective conditions. ${ }^{77}$ In those countries, fixed-term employment is percieved as precarious for workers who, after the end of one or more successive fixed-term contracts, can find themselves in the labour market in a precarious position, both from the legal and financial standpoint. The risk of unemployment is very high. ${ }^{78}$

Directive 99/70/EC in clause 4 prescribes the protection of fixed-term workers from discrimination in relation to the comparable permanent workers. This principle was also used as a tool against the income precariousness, i.e. to equalize fixed-term

75 Nestić, D; Blažević Burić, S., Radnici na minimalnoj plaći i siromaštvo u Hrvatskoj, Revija za socijalnu politiku, vol. 25, no. 3, 2018, p. 260. Cf. Grgurev, I.; Vukorepa, I., Minimum wage as a tool in the fight against poverty: Croatian labour law perspective, in: Löschnigg, G. (ed.), Staatliche Eingriffeindeas System der Mindestentgelte im internationalen Vergleich, Verlag des ÖGB, Wien, 2013, pp. 280-308

${ }^{76}$ Grgurev, I.; Vukorepa, I., Flexible and New Forms of Employment in Croatia and their Pension Entitlement Aspects, in: Sander, G.G. et al. (eds.), Transnational, European, and National Labour Relations, Springer Verlag, Heidelberg, Berlin, 2018, pp. 255, 259

77 Directive 99/70/EC defines fixed-term worker as a person having an employment contract (...) is determined by objective conditions such as reaching a specific date, completing a specific task, or the occurrence of a specific event

78 Lokiec, P., Fixed-Terms Contracts in France, Regulation of Fixed-term Employment Contracts, Comparative Labour Law Seminar, JILPT Report No. 9, 2010, pp. 43-53 
workers in the right to wage allowance based on seniority. ${ }^{79}$ Moreover, the Directive requires from Member States to take all necessary steps to prevent the misuse of the fix-term contracts ${ }^{80}$ and introduce, taking into account the needs of specific sectors and/or categories of workers, one or more of the following measures: objective reasons justifying the renewal of such contracts or relationships; the maximum total duration of successive fixed-term employment contracts or relationships $;{ }^{81}$ the number of renewals of such contracts or relationships. ${ }^{82}$ This led to variations between Member States contributing to a greater level of segmentation in the labour market. ${ }^{83}$ Precariousness inherent to fixed-term employment contracts arises from a lack of adequate protection against the employers first use of fixed-term contract, in relation to which the Framework agreement does not request from Member States to prescribe restrictions. The Member States were thus forced to individualy restrict the initial use of first fixed-term contract given the non-regression clasue that allows them to upgrade protection in favorem laboratoris. ${ }^{84}$

An approach to discourage the use of temporary contracts included restriction of their use, but also a deregulation of the SER, of redundancies etc. ${ }^{85}$ Some reforms have effected labour institutions in a positive way increasing the quality of work in standard and in promoted atypical employment, while others acted in the opposite direction towards precarization. For example, the reform in Spain (in the period 2000 - 2015) led to a decreasing of labour standards and employment protection and an increasing of precariousness. ${ }^{86}$

79 Joined Cases C-444/09 and C-456/09 Rosa María Gavieiro Gavieiro (C-444/09), Ana María Iglesias Torres (C-456/09) v Consellería de Educación e Ordenación Universitaria de la Xunta de Galicia [2010] OJ C 55/14

80 Joined Cases C-103/18 Sánchez Ruiz and C-429/18 Fernández Álvarez and Others v Comunidad de Madrid (Servicio Madrileño de Salud), Luxembourg, 19.3.2020. Member states should not from the notion „successive employment relationships on fixed-term” exclude a situation of a worker who was employed long-term, based on several engagements, as the substitution for the job without a public tender, whereby his employment relationship was tacitly prolonged from one year to another

81 Case C-212/04 Konstantinos Adeneler and Others v Ellinikos Organismos Galaktos (ELOG) [2006], ECR I-06057. Successive fix-term contracts where there is a gap of more then 20 days between them as instrument for employers to re-employ after a short break

82 Clause 5.1 of the Framework Agreement on fixed-term contract. Case C-212/04 Konstantinos Adeneler and Others v Ellinikos Organismos Galaktos (ELOG) [2006], ECR I-06057

83 Kahn, L. M., Employment protection reforms, employment and the incidence of temporary jobs in Europe: 1996-2001, Labour Economics, vol. 17, no. 1, 2010, pp. 1-15

84 Davies, A.C.L., EU Labour Law, Edward Elgar Publishing, Oxford, 2011, p. 191

85 More: Eurofound,2020, Labour market change, note 7, p. 43

86 Davies, op. cit., note 85, p. 191 
The Croatian Labour Act, ${ }^{87}$ as lex generalis for individual and collective employment relations, ${ }^{88}$ explicitly prescribes that the fixed-term employment contract can be concluded exceptionally, ${ }^{89}$ what ,implies that such contracts are seen as an atypical form of employment and that priority should be given to standard forms of employment." ${ }^{\prime 0}$

As fixed-term contracts can be concluded as a very short term to long term temporary contract, workers are faced with temporal precariousness. The employer may enter into a successive fixed-term employment contract with the same worker solely on objective grounds ("opravdani razlozi"), that must be specified in the contract, Art. 12 (2). It is important to emphasize that for the conclusion of the first fixedterm contract the objective ground is not needed (Art. 12 (4), in con. with (2).

The cumulative (maximum) duration of all successive fixed-term employment contracts, including the first employment contract, may not exceed three consecutive years, unless where it is necessary for the purpose of replacing a temporarily absent worker or where it is based on objective grounds allowed by law or a collective agreement (Art. 12 (3). The maximum duration of three consecutive years do not apply to the first fixed-term employment contract (Art. 12 (4). This means, for example, that the first fixed-employment contract could be concluded for five or seven years. But if the first contract is concluded for the period shorter than three years, and subsequently new contract(s) are concluded, a limitation of three consecutive years applies to all the concluded contracts. Also, another issue here is whether the employer and worker after the first fixed-term contract concluded for a period longer than three years, can conclude successive fixed-term contract(s) (i.e. with the duration of up to three years) or not? Opinions on the matter differ, ${ }^{91}$ leaving the final say to the judicature. According to the Supreme Court case law, the uninterrupted 3-year period should also include the period of work the same worker performed for the same employer,

$87 \quad$ Zakon o radu, Official Gazzete 93/2014, 127/2017, 98/2019

88 Employment relationships in Croatia are regulated by more than 20 other laws, besides Labour Act, that makes labour law legislation complex and increasingly fragmented. Grgurev; Vukorepa, op. cit., note 76 , p. 245

89 For the purpose of taking up an employment where the end of the employment is determined by a specific date, the completion of a specific task, or the occurrence of the specific event (Art. 12 (1))

90 Grgurev, I., Atypical Employment Relationships: The Position in Croatia, in: Waas, B.; van Voss, G. H. (eds.), Restatement of Labour Law in Europe, vol. II, Atypical Employment Relationships, Hart, Oxford, 2019, p. 84

91 Rožman, K., in: Detaljni komentar Zakona o radu, Rožman K. (ed.), Radno pravo, Zagreb, 2017, p 112; Kasunić Peris, M., in: Zakon o radu s komentarima i tumačenjima, Bejaković, P. et al. (eds.), TIM press, Zagreb, 2014, p. 120; Milković, D., Sporna pitanja novog Zakona o radu, in: Aktualnosti hrvatskog zakonodavstva i pravne prakse, vol. 22, Organizator, Zagreb, 2015, p. 142-143 
but as an assigned temporary agency worker. Otherwise, a circumvention of the strict rule at the detriment of worker would occur. ${ }^{92}$

Temporal precariousness is additionaly increased by allowing exceptions to the rule on the three-year maximum duration of successive fixed-term contracts, when it is „based on objective grounds allowed by law ${ }^{93}$ or by a collective agreement."

On the other hand, several legal presumptions improve the position of fixed-term workers, ${ }^{94}$ and represent an element of security. However, Croatian workers are often reluctant to claim their rights from the employer or before the court, afraid of losing their job. The Ombudswoman of the Republic of Croatia reports that "many workers have fixed-term work contracts, often concluded against the law, while employers patently exploit this institute", and aware of this and dissatisfied with their insecure employment status, "workers put up with it, hoping to be offered permanent work contracts if they prove they deserve it through their work and efforts." ${ }^{95}$ Labour inspectors note the violations related to the illegal conclusion of the fixed-term contracts (Art. 228 (1/1). ${ }^{96}$ In 2017, they amounted to $6 \%$ of the total number of violations, and included 215 workers (110 women), compared to 2016 and a share of $7 \%$ (228 workers, 121 women). ${ }^{97}$

The temporal precariousness of fixed-term work ${ }^{98}$ reflects in the level of workers' rights, although they should be guaranteed in line with the principle of equal treatment. Croatian LA safeguards in line with EU employment law, the same rights to fixed-term workers as to the "comparable workers" 99 on an open-ended

92 Supreme Court (Vrhovni sud RH, Revr 649/2018-2, 9.4.2019). The justification the employer used for the conclusion of successive fixed-term contracts was the "temporary" increase of work, that lasted almost six years, and the Court concluded that he had a permanent need for the worker

93 See: Grgurev, op. cit., note 90, p $87 \mathrm{ff}$

94 Provisions regulating legal presumptions in case of fixed-term contracts: Art. 12 (5), (6) and (7); Art. 11 (3) LA

95 Annual Ombudsman Report for 2018, p 85-89, [https://www.ombudsman.hr/en/reports/], Accessed 25 April 2020 The situation with fixed-term contract is depicted in a complaint from " ... a former employee, who had concluded 54 fixed-term work contracts with this employer during a 15-year period. Inspection found that concluding these contracts was not in contravention of the LA, and the employer received approval from the workers' council in this specific case, too." The Report emphasized that such excessive number of fixed-term work contracts „....creates a feeling of insecurity contributing to decisions made by both the employed and unemployed to look for work outside the RC."

96 Serious offences by employers, Article 228 (1), accompanyed with a fine in an amount ranging from HRK $31,000.00$ to $60,000.00$ (cca $4.100-8.000$ EUR)

${ }_{97}$ Izvješće o radu Inspektorata rada (2016; 2017), [http://haw.nsk.hr/arhiva/vol2018/4734/76272/www. $\mathrm{mrms} . h \mathrm{r} / \mathrm{ministarstvo-rada-i-mirovinskoga-sustava/inspektorat-rada/index.html],} \mathrm{accessed} \mathrm{on} 26$. April 2020

98 See Kountouris, op. cit., note 19, p. 30

99 See Art. 13(1-3). More: Grgurev, op. cit., note 90, p. 89-90 
contract, but in practice there are numerous challenges. Without a doubt, fixedterm workers have smaller chances because the employer usually has no or little interest to invest in the education of temporary staff. Consequently, they are in an awkward position in achieving the opportunities for education, and also for life-long learning, and therefore more vulnerable in terms of their position in the labour marked in order to improve their employability by acquiring the right skills for the labour market. Also, the employer is, according to the Art. 13 (4) of LA, obligated to inform the fixed-term workers about assignments for which these workers could enter into an employment contract of indefinite duration (Art. 13 par. 4, LA). Due to a rather imprecise provision that does not regulate how and when the worker should be informed, the realization of workers's right is doubtful. More precise regulation is hence needed de lege ferenda. ${ }^{100}$

The analysis of the fixed-term work regulation and judicature leads us to a conclusion that there are significant gaps in the regulation of this non-standard form of employment enabling abuse of this type of employment on behalf of the employ$\mathrm{er}$, and rendering it therefore even more precarious than intrinsically. Some of the solutions de lege ferenda against precariousness could be: to limit the number of successive fixed-term contracts (as in some other national legislations of Member States, e.g. France) and to strengthen the role of labour inspection in controlling the abuses of this form of employment, possibly by introducing more effective measures, i.e. authorizing the labour inspector to order the employer who committed a violation to conclude the open-ended contract with the same worker. Under the current LA, the worker is entitled to severance payment only after two years of continuous employment with the same employer, whereas one of the options could be the introduction of the Austrian institution of Vorsorgekasse. ${ }^{101}$

A concerning factor is that Croatia is among countries with the highest overall proportion of precarious employment mostly present in agriculture, retail trades and catering activities, most notably because of the importance of tourism for the Croatian economy and because of its seasonality. ${ }^{102}$ However, other factors, institutional (labour legislation), technological (digitalisation) and economic (employers' caution, decrease of the total labour cost) play an important role as well. ${ }^{103}$

\footnotetext{
100 Similar problem is visible when the same right of TAW is concerned

101 More: [https://www.oenb.at/Publikationen/Statistik/Finanzstatistik/Betriebliche-Vorsorgekassen. html], accessed on 28. April 2020

102 In 2016 it amounted to $8.4 \%$, while the EU average was $2.3 \%$ of the employees who had a precarious job. In 2018 the average decreased to $6.8 \%$. [ https://ec.europa.eu/eurostat/en/web/products-eurostat-news/-/DDN-20180209-1], accessed on 16. April 2020

103 Tomić et al., op. cit., note 68, p 11.
} 
A significant reconfiguration of the employment status in Croatia is the result of a shift from self-employment to temporary employment, which places Croatia, together with Spain, in the group of Member States with the highest share in growth of temporary work. ${ }^{104}$ Statistics provided by the Croatian Pension Insurance Fund (HZMO) show that a quarter of Croatian employees have fixed-term contracts, while the lion's share of the newly employed, that is $90 \%$ of them, are temporary workers, which is why unionists warn that the government-sponsored measures to boost employment are inefficient. ${ }^{105}$ Slovenia, for example, found itself in the group of Member States with the highest proportion of fixed-term employment contracts in the past 15 years, rendering this practice, as Senčur Peček and Franca rightly note, the rule, rather than an exception. ${ }^{106}$

A further problematic trend is the shortening of the duration of temporary contracts, observed in most EU Member States. As a matter of fact, the incidence of precarious casual work resp. short-term temporary contracts with a maximum duration of three months (precarious temporary employment) amounts to over $30 \%$ in Croatia in contrast to the stable EU average of $19 \%$. It should be emphasized that Croatia is in the group of countries in which in 2018 over one-third of younger workers were on short-duration contracts (the Baltic states, Belgium, Finland, Hungary and Sweden). ${ }^{107}$

\section{GIG-ECONOMY - HOW TO COMBAT VIRTUAL PRECARIOUS WORK?}

The economy of atypical, i.e. casual work as the product of the so-called gig economy is constantly growing ${ }^{108}$ and represents the beginning of the end of permanent employment, and a temporary solution of existential problems. ${ }^{109}$ The core of gig economy, more often called sharing economy, is a phenomenon of the labour market, i.e. a bussines-strategy oriented to use technological revolution to achieve the main goal of the entrepreneur, namely, the optimization of cost.

\footnotetext{
104 Temporary employees as percentage of the total number of employees. Source of data: Eurostat. 26.4.2020

105 HZMO: [http://www.mirovinsko.hr/default.aspx?id=4298], accessed on 14. April 2020

106 Senčur Peček, D.; Franca, V., From student work to false self-employment: how to combat precarious work in Slovenia?, in: Kenner, J. et al. (eds.), Precarious work: towards a new theoretical foundation, The challenge for Labour Law in Europe, Edward Elgar, Cheltenham, Northampton, 2019, p. 120

107 Eurofound (2020), note 7, p 39

108 Eurofound (2018a), note 30; cf. Bjelinski, I., Izazovi radnog i socijalnog prava u svjetlu digitalizacije rada, Zagrebačka pravna revija, vol. 8, no. 3, 2018, p. 315

109 For an opposing opinion see: The Future Organisation, [https://thefutureorganization.com/wp-content/uploads/2018/04/Paul-Oyer-Transcript.pdf], accessed on 03. March 2020
} 
The impact of the technological revolution on the transformation of the Croatian labour market is visible in the increase of employment and atypical forms of employment to perform digital services. It is a big challenge for employers, workers, and especially the legislator that should respond by creating a new regulatory framework, with the guarantee of decent working conditions and employment in new jobs, with precisely defined rights and duties of the contractual parties. ${ }^{10}$

In the context of organizational precariousness, ICT workers can face the flip side of long working hours, especially for self-employed whose work is mostly based on the use of digital technology, e.g. platform-work (ICT-mobile work and telework). ${ }^{111}$ In practice, employers often use the lack of precise (legal) indicators of the employment relationship circumventing the law to disguise such work as bogus self-employment, or the worker is in fact economically dependant of one employer (dependent self-employment). Due to this, virtually organized work reminds of a manipulation of the labour status in which the workers carry all risks that are not shared with the employer. ${ }^{112}$

In Croatia, a prominent example of such practice in the IT sector seems to be using the possibility to pay lower taxes by allowing workers to register as independent craftpersons paying lump-sum taxes through the so-called flate-rate craft sheme. ${ }^{113}$ There is further research however showcasing that standard employment remains significant in this field. ${ }^{114}$ The institution of telework represents a flexible solution that enables a work-life balance, but its indicator of insecurity is reflected in the shaping of working time individually, rendering the organization of private duties the more difficult. ${ }^{15}$ Workers should permanently partake in professional training, and pay the costs therefor mostly themselves, without a real possibility for promotion. Precarisation of ICT work is visible from its temporary nature, especially in the case of short-term projects.

110 [http://www.europarl.europa.eu/doceo/document/A-8-2017-0224_HR.html], accessed on 03. March 2020

111 Eurofound (2020a), Telework and ICT-based mobile work: Flexible working in the digital age, Publications Office of the European Union, Luxembourg, 2020

112 Therefore, we rightly wonder are freelancer genuinely "free"? ILO (2018), Work On Digital Labour Platforms In Ukraine: Issues And Policy Perspectives, International Labour Office, Geneva, 2018, p. 32

113 Tomić et. al., note 68, p. 12

114 Laleta, S., Innovation and growth of skills: Challenges to the Croatian legislature, Zbornik Pravnog fakulteta Sveučilišta u Rijeci, vol. 39, no. 4, 2018, pp. 1865, 1870

115 Directive 2019/1158 of the European Parliament and of the Council on work-life balance for parents and carers and repealing Council Directive 2010/18/EU [2019] OJ L 188/79 (Work-Life Balance Directive) 
In Croatian legislation, ICT mobile work is regulated inside the broader concept of the employment at an alternative workplace (Art. 17, LA). It includes "works to be performed at the worker's home or outside the employer's premises", under conditions regulated by the Protection at Work Act. ${ }^{116}$ Such regulation guarantees the same employment rights as of a standard worker, and safe working conditons. ${ }^{117}$ Provisions of the LA that regulate this institute are in line with the European standards, ${ }^{118}$ enabling full antidiscrimination and safety at work protection, remuneration for work (salary) and obligatory social insurance. ${ }^{119}$ However, in practice workers often cannot control the organization of work (organizational precariousness) due to the overload and expectations of the employer, which can cause health problems (burnout). The situation with COVID-19 pandemic and the transfer of work to home as an alternative workplace coupled with the abundant use of ICT technology (working online) has clearly demonstrated that this type of work deserves to be regulated as an autonomous institute as soon as possible.

\section{CASUALISATION OF EMPLOYMENT}

Casual work is described as work which is irregular or intermittent, without prospects of continuous employment. Depending on the type of contract, the employer arbitrarily determines maximum or minimum working hours, but can also refrain from the latter (zero-hour). ${ }^{120}$ In other words, precariousness manifests itself in the absence of guaranteed hours of work and the employer's duty to provide worker with work or a task. ${ }^{121}$ Typicial characteristics are: very insecure demand (casual), or even no demand for certain services/work that should be performed in certain time limits with no guarantee that the employment relationship will be prolonged; unpredictable and irregular working time; low wages and limited access to benefits. The satisfaction of worker is lower due to a disorderly work re-

116 Zakon o zaštiti na radu, Official Gazette, 71/14, 118/14, 154/14, 94/18, 96/18. The employer no longer has a duty to write a risk evaluation for work performed on alternative workplace temporarily

117 According to old Labour Act, Official Gazette, 149/09, 61/11, 82/12 i 73/13, the employer had to inform the labour inspection about every contract that stipulates flexible organization of working time or work outside the employer's premissses. The cancellation of this duty has relaxed the conclusion of such contracts. We are of the opinion that such legislative intervention represented a means to prevent manipulations with insecure forms of employment

118 The biggest step in the modernizaton of the work organization, including flexible forms of employment, in order to achieve the purpose of the concept of flexicurity, has been made with the European (autonomous) Framework Agreement of Telework, 2002

119 Bilić, A., Rad na daljinu prema međunarodnom, europskom i hrvatskom radnom pravu, Zbornik radova Pravnog fakulteta u Splitu, vol. 48, no. 3, 2011, p. 636

120 Eurofound (2019), note 54, pp. 3-4

121 Adams, A. et al., The 'zero-hours contract': Regulating casual work, or legitimating precarity?, Oxford Legal Studies Research Paper No. 11, University of Oxford, Oxford, 2015, pp. 1-21 
lationship, while the strong flexibilization makes off-work time organization more difficult. ${ }^{122}$

It is evident that casual workers do use the given chances to work, afraid of what might happen if they rejected them. ${ }^{123}$ In addition, they fear because of the exclusivity clauses included in a particular type of casual contracts that demand workers to be available everyday, at any time, making it impossible to take another job. ${ }^{124}$

In Croatia casual work is performed outside the employment relationship, based on civil-law contracts (contract for services and works, student contracts, occupational training contracts) or by self-employed persons. ${ }^{125}$ Those alternative forms of employment are not regulated by the Labour Act and therefore higly precarious in particular in regard to income, social security, access to education and other working conditions. ${ }^{126}$ For example, student work as rather frequent and cheap work often assumes all the elements of an employment relationship in practice; nevertheless, due to the old-new regulation, it is still regulated as a contract for services.

It is worth mentioning that self-employed journalists or similar professions in the media often work based on a civil-law contract, but perform work that has all the characteristics of an employment relationship (bogus self-employment). ${ }^{127} \mathrm{In}$ many court cases self-employed persons have hence claimed that the work they performed was in fact tantamount to an employment relationship. Surprisingly, the Supreme Court of Croatia has expressed an doubtful opinion in several cases asserting that the elements proved in trial (e.g. subordination, working hours, work performed at the employer's premises) which are indicators of an employ-

122 According to research conducted in the UK, more than $60 \%$ of the interviewed work in precarious working conditions. This creates a lower standard of skills in the workforce and permanent insecurity. See: [https://theconversation.com/zero-hours-contracts-have-a-devastating-impact-on-career-progression-labour-is-right-to-ban-them-123066], 19 January 2020. Also: ILO (2004), On-call work and 'zero hours' contracts, International Labour Office, Geneva, 2004, p. 3

123 For EU intervention see: The Directive on Transparent and Predictable Working Conditions

124 In the UK, exclusivity clauses in zero-hours contracts are prohibited by a law dating back to May 2015. See: Commission Staff Working Document Executive Summary Of The Impact Assessment Accompanying the document Proposal for a Directive of the European Parliament and of the Council on transparent and predictable working conditions in the European Union $\{\mathrm{COM}(2017) 797 \mathrm{final}\}$ -\{SWD(2017)478final, Brussels, 2017

125 As I. Vukorepa et al. stated there is no official definition or meaningful statistics concerning the number of bogus and dependent self-employment. Vukorepa, I. et al., ESPN Thematic Report on Access to social protection of people working as self-employed or on non-standard contracts, Croatia, ESPN, EC, 2017, p. 6

126 Butković; Samaržija, op. cit., note 8, p. 26

127 Vukorepa et al., op. cit., note 125, p. 6 
ment relationship according to the ILO Recommendation, ${ }^{128}$ were not relevant because they could also be conceived of as elements of a civil-law relationship, and that priority should be given to the intention of the contractual parties. ${ }^{129}$

The Croatian Ministry of Culture has recently adopted a special regulation for specific groups of self-employed persons, like freelance artists who lost all income due to the theater, museums and music halls shutdown in the midst of the COVID-19 pandemic. ${ }^{130}$

\section{INSTEAD OF A CONCLUSION}

By uncritically accepting the global market trends, economies expose the labour market to new rules of the game that limit government intervention, thereby relaxing legal frameworks and protective collective mechanisms. Such exposure to modernization has indeed influenced the transformation of the labour organization enabling employers an autonomous determination of employment and working conditions.

Globalization has not eluded a microeconomy as Croatia, whose labour market, due to ambitious aspirations and imperatives of reducing labour costs and competitiveness leads to a permanently uncertain and despondent business policy. ${ }^{131}$ The decline of work quality made insecurity in the form of precariousness present not only in all segments of the employment relationship, but also in all aspects of the human life. Many recognize their own experience, which is why the need to articulate the issue of precariousness within scientific and academic circles is gaining prominence. Nevertheless, the conflict of interests in the world of labour full of emerging novelties and expectations requires an adequate labour law intervention and optimal solution for the traditional employer-employee conflict, bearing in

128 Employment Relationship Recommendation, 2006 (No. 198) - Recommendation concerning the employment relationship, Geneva, 95th ILC session (15 Jun 2006)

129 Supreme Court of RC, judgments: VSRH, Revr 409/13-2, 17.12.2013; VSRH, Revr 657/142, 2.12.2014; VSRH, Revr 648/13-3, 9.9.2014; VSRH, Revr 177/15-2, 15.9.2015; VSRH, Revr 1536/13-3, 9.6.2015. For the employment relationship's indicators in case law see: Grgurev, I., The Concept of 'Employee': The Position in Croatia, in: Waas, B.; van Voss, G. H. (eds.), Restatement of Labour Law in Europe, Vol I: The Concept of Employee, Hart Publishing, Oxford and Portland, Oregon, 2017, p. 76 ff

130 Government measures for culture, [https://www.koronavirus.hr/vladine-mjere/mjere-za-kulturu/133], accessed on 25. April 2020

131 For the decline of job quality in Croatian tourism sector see: “Turizam i ljetne migracije“ $\mathrm{i}$ „Turizam $i$ rad" in journal Rad, br. 3, rujan, 2015 
mind the legislator's role in creating precariousness through unclear provisions and courts' discretion to interpret. ${ }^{132}$

In consideration of the above, this paper has attempted to point out the conceptual issue of the phenomenon in all its socio-economic dimensions in order to highlight the continuous practice of labour exploitation and overproduction of today's precarious labour army. ${ }^{133}$

The pandemic caused by the corona virus (COVID-19) in March 2020 has flabbergasted the world. A new wave of economic crisis has once again displayed a lack of empathy in the political reality and the business sector, which, as Athrey vividly states, have no room for financial losses and continue to "celebrate" the gig economy from the security of their homes considering the best ways to exploit precarious workers. ${ }^{134}$

ILO has reported that approximately 25 million workers will lose their jobs, which has more far-reaching consequences than those caused by the 2008 recession. An initial assessment of the impact of COVID-19 on the global work world, in addition to millions unemployed and in-work poverty, admonishes that the labour market crisis will disproportionately affect vulnerable workers engaged in lowpaid jobs consequently leading to social exclusion and rise of inequality. ${ }^{135}$ This "economic fall" and erosion of work standards requires rapid and coordinated intervention on national and supranational level, primarily to protect the status of already disadvantaged workers. ${ }^{136}$

The aforementioned proponents of an affirmed neoliberal stance, whose basic premise implies an unrestricted labour market with an epidemiologically adjusted business policy continually provide services unaware of the health and safety risks their employees are exposed to, and unable to refuse to work under hazardous

\footnotetext{
132 Godlewska-Bujok; Patulski, op. cit., note 25, p. 25-26

133 Standing, G., Precariat: New Dangerous Class, London, Bloomsbury Academic, 2011, p. 16

134 Labour market participants at the top end are celebrating the rise of an economy reliant on precarious work that serves their interests, both as investors and consumers. Recent example of such exploitation is Amazon worker (not the only case) in a New York warehouse tested positive for coronavirus. Yet Amazon refused to provide sick leave to employees. Amazon denies this. See: The Gig Economy to the Rescue, The flexibility of app services is helping millions in the panic, The Wall Street Journal, 2020, [https:// www.wsj.com/articles/the-gig-economy-to-the-rescue-11584573142] including: [https://www.theatlantic.com/health/archive/2020/03/amazon-warehouse-employee-has-coronavirus/608341/], accessed on 03. May 2020

135 COVID-19 and the world of work: Impact and policy responses, ILO Monitor $1^{\text {st }}$ Edition, 2020, p. 2-3

136 Ibid.
} 
conditions. ${ }^{137}$ The question thus arises as to how the labour market will challenge laid-offs in a situation of much-needed "cost-cutting", given that most gig-works do not include social benefits which are pivotal at a time of a global pandemic. Within such precarious economy, terminating employment contracts of marginal employees accounts for a textbook economic activity typical of the world labour market. ${ }^{138}$

\section{REFERENCES}

\section{BOOKS AND ARTICLES}

1. Adams, A. et al., The 'zero-hours contract': Regulating casual work, or legitimating precarity?, Oxford Legal Studies Research Paper no. 11, University of Oxford, Oxford, 2015, pp. 1-21

2. Bejaković, P., Prekarni rad u Hrvatskoj i Europi, Radno pravo, no. 7-8, 2019, pp. 32-38

3. Bilić, A., Rad na daljinu prema međunarodnom, europskom i hrvatskom radnom pravu, Zbornik radova Pravnog fakulteta u Splitu, vol. 48, no. 3, 2011, pp. 631-647

4. Bjelinski, I., Izazovi radnog i socijalnog prava u svjetlu digitalizacije rada, Zagrebačka pravna revija, vol. 8, no. 3, 2018, pp 309-331

5. Bodiroga, Vukobrat, N. et al., Precarious Times, Precarious Work: Lesson from Flexicurity, in: Wolfrum, R. et al. (eds.), Contemporary Developments in International Law. Essays in Honour of Budislav Vukas, Brill Nijhoff, Leiden, Boston, 2016, pp. 405-430

6. Butković, H.; Samardžija, V., Nestandardni rad u Hrvatskoj: Izazovi i perspektive u odabranim sektorima, IRMO, Zagreb, 2018

7. Campbell, I.; Price, R. Precarious work and precarious workers: Towards an improved conceptualisation, The Economic and Labour Relations Review, vol. 27, no. 3, 2016, pp. 314-332

8. Countouris, N., Strengthening the protection of precarious workers: the concept of precarious work, ITC, London <s.a.>

9. Davies, A.C.L., EU Labour Law, Oxford, 2011

10. Eurofound (2017), Aspects of nonstandard employment in Europe, Dublin, Eurofound, 2017

11. Eurofound (2017a), Estimating labour market slack in the European Union, Publications Office of the European Union, Luxembourg

12. Eurofound (2017b), Non-standard forms of employment: Recent trends and future prospects, Eurofound, Dublin, 2017

13. Eurofound (2018), Does employment status matter for job quality?, Publications Office of the European Union, Luxembourg

137 Need to go out and don't want to face public transportation? Just order car service from Uber or Lyft. Want to avoid crowded grocery stores? Instacart has you covered! Can't go to your favorite restaurant? There's an app for that, too. See also: Fair working conditions in Germany, [https://www.fair-arbeiten. $\mathrm{eu} / \mathrm{hr} /$ article/460.faq-corona-virus.html], accessed on 30. May 2020

138 For effects of interrupted business operations on employment and respond of the Croatian goverment through financial support for employers see: Grgurev, I., COVID-19 and Labour Law: Croatia, 2020, [https://illej.unibo.it/article/view/10773/10682], accessed on 19. April 2020 
14. Eurofound (2018a), Non-standard forms of employment: Recent trends and future prospects, Eurofound, Dublin, 2018

15. Eurofound (2019), Labour market segmentation: Piloting new empirical and policy analyses, Publications Office of the European Union, Luxembourg

16. Eurofound (2020), Labour market change: Trends and policy approaches towards flexibilisation, Challenges and prospects in the EU series, Publications Office of the European Union, Luxembourg

17. Eurofound (2020a), Telework and ICT-based mobile work: Flexible working in the digital age, Publications Office of the European Union, Luxembourg, 2020

18. Florczak, I. et al., Precarious work and labour regulation in the EU: current reality and perspectives, in: Kenner, J. et al. (eds.), Precarious work: towards a new theoretical foundation, The challenge for Labour Law in Europe, Edward Elgar, Cheltenham, Northampton, 2019, pp. 2-21

19. Fudge, J.; Owens, R., Precarious Work, Women, and the New Economy: The Challenge to Legal Norms, in: Fudge, J.; Owens, R. (eds.), Precarious Work, Women, and the New Economy: The Challenge to Legal Norms, Hart Publishing, 2006

20. Garben, S. et al., Towards a European Pillar of Social Rights: Upgrading the EU social aquis, Theorising the ENP - Conference Report, 2015, College of Europe Policy Brief No. 1, 2017

21. Godlewska-Bujok, B.; Patulski, A., Precariat: next stage of development or economic predominance in a new scene?, in: Kenner, J. et al. (eds.), Precarious work: towards a new theoretical foundation, The challenge for Labour Law in Europe, Edward Elgar, Cheltenham, Northampton, 2019, pp. 22-37

22. Grgurev, I., Atypical Employment Relationships: The Position in Croatia, in: Waas, B.; van Voss, G. H. (eds.), Restatement of Labour Law in Europe, Volume II, Atypical Employment Relationships, Hart, Oxford, 2019, pp. 83-105

23. Grgurev, I., The Concept of 'Employee': The Position in Croatia, in: Waas, B.; van Voss, G. H. (eds.), Restatement of Labour Law in Europe, Vol I: The Concept of Employee, Hart Publishing, Oxford and Portland, Oregon, 2017, pp. 59-83

24. Grgurev, I.; Vukorepa, I., Flexible and New Forms of Employment in Croatia and their Pension Entitlement Aspects, in: Transnational, European, and National Labour Relations, Sander, G.G. et al. (eds.), Springer Verlag, Heidelberg, Berlin, 2018, pp. 241-262

25. Grgurev, I.; Vukorepa, I., Minimum wage as a tool in the fight against poverty: Croatian labour law perspective, in: Löschnigg, G. (ed.), Staatliche Eingriffeindeas System der Mindestentgelte im internationalen Vergleich, Verlag des ÖGB, Wien, 2013, pp. 280-308

26. Henning, J. et al., Flexicurity and Beyond. Finding a new agenda for the European Social Model, DJØF Publishing, Kopenhagen, 2007

27. Hromadžić, H.; Zgaljardić, A., Prekarnost, Ekonomsko-politički i društveni fenomen suvremenog svijeta, Etnološka tribina 42, vol. 49, 2019, p. 122-136

28. Kahn, L. M., Employment protection reforms, employment and the incidence of temporary jobs in Europe: 1996-2001, Labour Economics, vol. 17, no. 1, 2010, pp. 1-15

29. Kasunić Peris, M., in: Bejaković, P. et al. (eds.), Zakon o radu s komentarima i tumačenjima, TIM press, Zagreb, 2014 
30. Kountouris, N., The Legal Determinants of Precariousness in Personal Work Relations: A European Perspective, Comparative Labour Law \& Policy Journal, vol. 34, no. 1, 2012, pp. 21-46

31. Laleta, S., Innovation and growth of skills: Challenges to the Croatian legislature, Zbornik Pravnog fakulteta Sveučilišta u Rijeci, vol. 39, no. 4, 2018, pp. 1851-1880

32. Lokiec, P., Fixed-Terms Contracts in France, Regulation of Fixed-term Employment Contracts, Comparative Labour Law Seminar, JILPT Report no. 9, 2010, pp. 43-53

33. Marshall, A., The Sequel of Unemployment, The Changing Role of Part-time and Temporary Work in Western Europe, in: Rodgers, G.; Rodgers, J. (eds), Precarious Job in Labour Market Regulation, Geneva, Institutional Institute for Labour Review, 129, 1989, pp. 17-30

34. Matković, T., Nestajanje rada? Opseg i oblici zaposlenosti na početku informacijskoga doba, Društvena istraživanja, vol. 13, no. 1-2, 2004, pp. 69-70

35. Milković, D., Sporna pitanja novog Zakona o radu, in: Aktualnosti hrvatskog zakonodavstva i pravne prakse, vol. 22, Organizator, Zagreb, 2015, pp. $131-172$

36. Nestić, D.; Blažević Burić, S., Radnici na minimalnoj plaći i siromaštvo u Hrvatskoj, Revija za socijalnu politiku, vol. 25, no. 3, 2018, pp. 235-262

37. Ori, M.; Sargeant, M., Introduction, in: Precarious Work and Vulnerable Workers, Vulnerable Workers and Precarious Working, International School of Higher Education in Labour and Industrial Relations, Cambridge Scholars Publishing, Newcastle upon Tyne, 2013

38. Peña-Casas, R. et al., In-work poverty in Europe, A study of national policies, European Social Policy Network (ESPN), Brussels, European Commission, 2019

39. Quinlan, M. et al., The Global Expansion of Precarious Employment, Work Disorganization, and Consequences for Occupational Health: A Review of Recent Research, International Journal of Health Services, vol. 31, no. 2, 2001, pp. 335-414

40. Rodgers, G., Precarious Work in Western Europe: The State of the Debate, in: Rodgers, G.; Rodgers, J. (eds.), Precarious Jobs in Labour Market Regulation: The Growth of Atypical Employment in Western Europe, ILO, Geneva, 1989

41. Rožman K. (ed.), Detaljni komentar Zakona o radu, Radno pravo, Zagreb, 2017

42. Senčur Peček, D.; Franca, V., From student work to false self-employment: how to combat precarious work in Slovenia?, in: Kenner, J. et al. (eds.), Precarious work: towards a new theoretical foundation, The challenge for Labour Law in Europe, Edward Elgar, Cheltenham, Northampton, 2019, pp. 114-132

43. Standing, G., Precariat: New Dangerous Class, Bloomsbury Academic, London, 2011

44. Starčević, M., Prekarni rad i nemogućnost prekarne klase, Diskrepancija, vol. 13, no. 19, 2014, pp 37-57

45. Stone, Katherine V. W., From Widgets to Digits, Employment Regulation for the Changing Workplace, Cambridge University Press, USA, 2004

46. Vukorepa, I. et al., ESPN Thematic Report on Access to social protection of people working as self-employed or on non-standard contracts, Croatia, ESPN, EU, 2017

47. Westregård, A., Is Permanent Employment the Solution? Precarity on new forms of employment under Swedish labour law, in: Kenner, J. et al. (eds.), Precarious work: towards a new theoretical foundation, The challenge for Labour Law in Europe, Edward Elgar, Cheltenham, Northampton, 2019, pp. 99-113 
48. Wilthagen, T. et al., Flexicurity Pathways: Turning Hurdles into Stepping-Stones, Brussels, 2007

\section{COURT OF JUSTICE OF THE EUROPEAN UNION}

1. C-103/18 Sánchez Ruiz and C-429/18 Fernández Álvarez and Others v Comunidad de Madrid (Servicio Madrileño de Salud), Luxembourg, 19.3.2020

2. C-177/10 Francisco Javier Rosado Santana v Consejería de Justicia y Administración Pública de la Junta de Andalucia (EU:C:2011:557, t. 66., 8.9.2011)

3. Case C-143/16 Abercrombie \& Fitch Italia Srl v Bordonaro, EU:C:2017:566, 19 July 2017.

4. Case C-212/04 Konstantinos Adeneler and Others v Ellinikos Organismos Galaktos (ELOG) [2006], ECR I-06057

5. Case C-38/13 Matgorzata Nierodzikv Samodzielny Publiczny Psychiatryczny Zaktad Opieki Zdrowotnej im. dr. Stanistawa Deresza w Choroszczy (EU: C:2014:152, 13.3.2014)

6. Case C-66/85 Deborah Lawrie-Blum v Land Baden-Württemberg, [1986] ECR 02121

7. Joined Cases C-444/09 and C-456/09, Rosa María Gavieiro Gavieiro (C-444/09), Ana María Iglesias Torres (C-456/09) v Consellería de Educación e Ordenación Universitaria de la Xunta de Galicia [2010] OJ C 55/14

\section{EU LAW AND DOCUMENTS}

1. Council Directive 1999/70/EC concerning the framework agreement on fixed-term work concluded by ETUC, UNICE and CEEP [1999], OJ L175/43

2. Council Directive 91/533/EEC on an employer's obligation to inform employees of the conditions applicable to the contract or employment relationship [1991] OJ L288/32 (Written Statement Directive)

3. Council Directive 97/81/EC concerning the Framework Agreement on part-time work concluded by UNICE, CEEP and the ETUC - Annex: Framework agreement on part-time work) [1997] OJ L 14/9 (Part-time Work Directive)

4. Directive 2008/104/EC of the European Parliament and of the Council on temporary agency work [2008] OJ L327/9 (Temporary Agency Work Directive)

5. Directive 2019/1152 of the European Parliament and of the Council on transparent and predictable working conditions in the European Union [2019] OJ L186/105

6. Directive 2019/1158 of the European Parliament and of the Council on work-life balance for parents and carers and repealing Council Directive 2010/18/EU [2019] OJ L 188/79 (Work-life Balance Directive)

7. European Commission, 'Staff Working Document REFIT Evaluation of the "Written Statement Directive” (Directive 91/533/EEC)' SWD (2017) 205 final

8. European Commission, Commission Staff Working Document: Analytical document accompanying the Consultation Document Second phase consultation of Social Partners under Article 154 TFEU on a possible revision of the Written Statement Directive (Directive 91/533/EEC) in the framework of the European Pillar of Social Rights, SWD (2017) 301 final, Brussels, 2017 
9. European Commission, Employment in Europe, Directorate-General for Employment, Social Affairs and Equal Opportunities Unit, 2007

10. European Commission, Non-standard employment and access to social security benefits, Research note 8/2015 (SMM_2015_RN8_non-standard employment_final (2).pdf)

\section{ILO DOCUMENTS}

1. COVID-19 and the world of work: Impact and policy responses, ILO Monitor $1^{\text {st }}$ Edition, 2020, p. 2-3

2. Employment Relationship Recommendation, 2006 (No. 198) - Recommendation concerning the employment relationship, Geneva, 95th ILC session (15 Jun 2006)

3. ILO (2004), On-call work and 'zero hours' contracts, International Labour Office, Geneva, 2004

4. ILO (2010), Report VI: Employment Policies for Social Justice and Fair Globalization, Geneva, 2010

5. ILO (2011), Policies and Regulations to Combat Precarious Employment, Bureau for Workers Activities, International Labour Office, Geneva, 2011

6. ILO (2012), From precarious work to decent work, Bureau for Workers' Activities, International Labour Office, Geneva, 2012

7. ILO (2016), Non-standard employment around the world, Understanding challenges, shaping prospects, International Labour Office, Geneva 2016

8. ILO (2018), Work On Digital Labour Platforms In Ukraine: Issues And Policy Perspectives, International Labour Office, Geneva, 2018

\section{LIST OF NATIONAL REGULATIONS, ACTS AND COURTS DECISIONS}

1. Labour Act (Zakon o radu), Official Gazette, No. 149/2009, 61/2011, 82/2012, 73/2013

2. Labour Act (Zakon o radu), Official Gazete, No. 93/2014, 127/2017, 98/2019

3. Protection at Work Act (Zakon o zaštiti na radu), Official Gazette, No. 71/2014, 118/2014, 154/2014, 94/2018, 96/2018

4. Supreme Court of RC (Vrhovni sud Republike Hrvatske), decisions: VSRH, Revr 409/132, 17.12.2013; VSRH, Revr 1536/13-3, 9.6.2015; Supreme Court, Revr 649/2018-2, 9.4.2019

\section{WEBSITE REFERENCES}

1. Annual Ombudsman Report for 2018, p. 85-89 [https:/www.ombudsman.hr/en/reports/], accessed on 25. April 2020

2. Austria [https:/www.oenb.at/Publikationen/Statistik/Finanzstatistik/Betriebliche-Vorsorgekassen.html], accessed 28 April 2020

3. Badoi, D., Normalizing precariousness through the flexible work-A conceptual model proposal for the precarization of early-stage workers in science and research, [http://www.inclusivegrowth. eu/files/Call-12/15-DBadoi-_paper.pdf], accessed 28 April 2020 
4. EP, Report on working conditions and precarious employment (2016/2221(INI)). [https:// www.europarl.europa.eu/doceo/document/A-8-2017-0224_EN.html], Accessed 10 March 2020

5. Eurofound (2015), New Forms of Employment, [https://www.eurofound.europa.eu/hr/ new-forms-of-employment\#case\%20studies], accessed on 03. March 2020

6. Eurofound, Precarious Work, [https://www.eurofound.europa.eu/observatories/eurwork/ industrial-relations-dictionary/precarious-work], accessed on 01. March 2020

7. Europan Pillar of Social Rights in 20 Principles, [https://ec.europa.eu/commission/priorities/deeper-and-fairer-economic-and-monetary-union/european-pillar-social-rights/european-pillar-social-rights-20-principles_en], accessed on 01. March 2020

8. European Commission, Launching a Consultation on a Euopean Pillar of Social Rights, $\operatorname{COM}(2016) 127$ final, Strasbourg, 2016, [https://eur-lex.europa.eu/resource.html?uri=cellar:bc4bab37-e5f2-11e5-8a50-01aa75ed71a1.0004.02/DOC_1\&format=PDF], accessed on 12. March 2020

9. Government measures for culture [https://www.koronavirus.hr/vladine-mjere/mjere-za-kulturu/133 22], accessed on 12. March 2020

10. Grgurev, I., COVID-19 and Labour Law: Croatia, 2020, [https://illej.unibo.it/article/ view/10773/10682], accessed on 19. April 2020

11. Grimshaw, D., et al., Reducing Precarious Work Protective gaps and the role of social dialogue in Europe, 2017, [https://www.epsu.org/sites/default/files/article/files/Precarious\%20 work\%20and\%20social\%20dialogue.pdf], accessed on 07. March 2020

12. Huws, U. et al., What price flexibility? The casualisation of women's employment, 1989, [https:// openaccess.leidenuniv.nl/bitstream/handle/1887/35203/What\%20price\%20flexibility.pdf? sequence $=1$ ], accessed on 01 . February 2020

13. Izvješće o radu Inspektorata rada u 2016. godini i Izvješće o radu Inspektorata rada u 2017. godini, [http://haw.nsk.hr/arhiva/vol2018/4734/76272/www.mrms.hr/ministarstvo-rada-i-mirovinskoga-sustava/inspektorat-rada/index.html], accessed on 26. April 2020

14. Izvješće o uvjetima rada i nesigurnosti radnih mjesta, Europski Parlament, 2017, [http:// www.europarl.europa.eu/doceo/document/A-8-2017-0224_HR.html], accessed on 26. April 2020

15. Kountouris, N., The Concept of 'Worker' in European Labour Law: Fragmentation, Autonomy and Scope, 2018, pp. 1-23, [https://discovery.ucl.ac.uk/id/eprint/1571889/1/Countouris_ Concept_Worker_European_AAM.pdf], accessed on 02. February 2020

16. Moj posao, [https://www.moj-posao.net/Press-centar/Details/68737/Izmedju-40-i-60-tisuca-ljudi-radi-a-ne-prima-placu/2/], accessed on 10. March 2020

17. Plus Goverment Report, [https://vlada.gov.hr/4-krug-porezne-reforme/26478], accessed on 26. April 2020

18. Precarious Employment in Europe: Patterns, Trends and Policy Strategies, Directorate General for Internal Policies, Policy Department, Economic And Scientific Policy European Parliament, 2016 [http://www.europarl.europa.eu/studies], accessed 03. March 2020 
19. Priopćenje Ankete o radnoj snazi za tromjesečno razdoblje od siječnja do ožujka 2019., [https://www.dzs.hr/Hrv_Eng/publication/2019/09-02-06_01_2019.htm], acccessed on 19. April 2020

20. Reform Labour Market Database, [https://webgate.ec.europa.eu/labref/public/result.cfm], accessed on 12. April 2020

21. Ross, S., The Rise of Precarity, Ontario Secondary School Teachers Federation magazine, Education Matters, Understanding and navigating the emerging economic and social (dis) order, 2017, [https://labourstudies.mcmaster.ca/news/the-rise-of-precarity], accessed on 12. April 2020

22. The Future Organisation, [https://thefutureorganization.com/wp-content/uploads/2018/04/ Paul-Oyer-Transcript.pdf], accessed on 26. April 2020

23. The Gig Economy to the Rescue, The flexibility of app services is helping millions in the panic, The Wall Street Journal, 2020, [https://www.wsj.com/articles/the-gig-economy-to-the-rescue-11584573142], [https://www.theatlantic.com/health/archive/2020/03/amazon-warehouse-employee-has-coronavirus/608341/], accessed on 03. May 2020

24. Tomić I. et. al., The employment and social situation in Croatia, Policy Department for Economic, Scientific and Quality of Life Policies, EU, 2019 [http://www.europarl.europa.eu/ supporting-analyses], accessed on 10. March 2020

25. Union of Autonomous Trade Unions of Croatia, Project: Work at the measure of workers, [http://www.sssh.hr/hr/vise/nacionalne-aktivnosti-72/rad-po-mjeri-covjeka-3446], accessed on 24. April 2020 